\title{
Conjugation Of Foot And Mouth Disease IgY In Chicken Egg Yolk With Horse Radish Peroxidase For Typing Of Foot And Mouth Disease Virus
}

\author{
Ehab El-Sayed Ibrahim ${ }^{1 *}$, Hamed Adel Hamed El-Helw ${ }^{1}$, Nermen Guda Shafik ${ }^{2}$ and Manal Awad Mekhail ${ }^{1}$
}

\author{
${ }^{1}$ Veterinary Serum and Vaccine Research Institute, svri@idsc.gov.eg. \\ ${ }^{2}$ Central Laboratory for Evaluation of Veterinary Biologics (CLEVB) \\ *Corresponding author's E-mail: ehabelsayed@ hotmail.com
}

\begin{abstract}
Through the present work, anti-FMD IgY immunoglobulins for serotypes O; A, and SAT2 were prepared in chicken egg yolk through immunization of laying hens with locally prepared trivalent FMD vaccine. The antibody titres against three serotypes (O; A, and SAT2) measured by SNT were 2.58; 2.8 and 2.6 respectively and where $2.81 ; 2.81$ and 2.8 respectively when measured by ELISA. Evaluation of Anti-FMD IgY conjugated with Horse radish peroxidase for detection of FMD virus in 100 tongue epithelium; 50 OP fluid samples; 20 nasal swabs from naturally infected cattle, and 100 tissue culture infected fluids revealed sensitivity of $85 \%$ indicating the success of preparation of anti-FMD immunoglobulins conjugated with horse radish peroxidase as local product available on request saving cost and time.
\end{abstract}

Original Article:

Key words: ELISA, FMD, immunization, PCR, Horse radish peroxidase, serotypes.

J. Appl. Vet. Sci., 2(1): 35-42

\section{INTRODUCTION}

Foot and Mouth disease (FMD) is a highly contagious disease of cattle, sheep, goats and pigs. Foot-and-mouth disease virus (FMDV) is the etiologic agent (a member in genus Aphthovirus in the family Picornaviridae) that can affect cloven-hoofed livestock. The virus exists in the form of seven serologically and genetically distinguishable types $(\mathrm{O}, \mathrm{A}, \mathrm{C}$, Asia1, SAT1, SAT2, and SAT3) but a large number of subtypes have evolved within each serotype (Neeta et al., 2011). The virus spreads by direct contact with infected animals, and indirect contact via contaminated animal products, animate and inanimate objects and by atmospheric dispersal. It causes an acute disease characterized by fever, lameness and vesicular lesions on the feet, tongue, snout and teats, with high morbidity and low mortality (Depa et al., 2012).

In Egypt, the disease is enzootic and many outbreaks have been reported since 1950. FMD serotypes SAT2, A and O were last reported in years 1950, 1972 and 2000, respectively (Aidaros, 2002). The type O was the most prevalent since 1960 and onwards (Farag et al., 2005 and Parida Satya, 2009). Serotype A was introduced to Egypt during 2006 through live animal's importation where sever clinical signs were recorded among cattle and buffaloes (Abd El-Rahman et al., 2006). In addition, serotype SAT-2 of FMD virus was later introduced to Egypt during
2012 also through live animal's importation (Shawky et al., 2013).

Immunoglobulins $\operatorname{IgY}$ are the predominant serum immunoglobulin in birds, reptiles, and amphibians, and transferred from blood (serum) to egg yolk as a maternal immunity to confer passive immunity to their embryos and neonates (Leslie and Clem, 1969). Domestic chickens (Gallus gallus) have been considered as an antibody factory of choice for some decades now and IgY (the primary serum immunoglobulin found in birds and reptiles) has been demonstrated as being efficacious in a range of immunological applications ranging from immunoassays to various proteomics applications (Karlsson et al., 2004). Indeed, using chicken as a host for antigen immunization and generation of polyclonal antibodies (IgY) has demonstrated several valuable advantages over existing mammalian systems.

This study was designed as an interesting work aiming to provide a specific kit conjugated with horse radish peroxidase to be available on the time of need to determine and typing FMD virus serotypes.

\section{MATERIALS AND METHODS}

\section{Virus serotypes and propagation:}

Foot and mouth disease virus serotypes (A IranO5, O Pan Asia and SAT-2/ Egypt 2012) were 
supplied by FMD Vaccine Research Department, Veterinary Serum and Vaccine Research Institute (VSVRI). The viruses were propagated twice in primary monolayer of bovine kidney cells then 6 serial passages in BHK21 monolayer cells obtained from Pirbright Surrey, UK according to Xuan et al., (2011). These viruses were used for vaccine preparation; serum neutralization test and antigen preparation for ELISA.

\section{Monovalent FMD vaccine:}

Monovalent FMD vaccines (O; A and SAT2) prepared according to Safy (2011) and Farag et al., (2011) were supplied by FMD Research Department, VSVRI and used for immunization of experimental chicken.

\section{Immunization of chickens:}

Twenty one 6 months old white specific pathogen free laying hens, obtained from Koum Oshem Farm were assign into 3 groups; each group containing 7hens. 3 Freund's adjuvant monovalent FMDV for each serotypes (A Iran5, O Pan Asia and SAT-2/ Egypt 2012) vaccines were emulsified with an equal volume of Freund's complete adjuvant for $1^{\text {st }}$ dose of vaccination. Group (1) vaccinated with FMD serotype O; Group (2) vaccinated with FMD serotype A, and group (3) vaccinated with serotype SAT2.

Each vaccine was inoculated $\mathrm{I} / \mathrm{M}$ in a dose of $1 \mathrm{ml} /$ hen. A second dose of vaccination was emulsified in Freund's incomplete adjuvant after 2 weeks receiving a booster dose after 4weeks of first vaccination. Blood samples from hens in each group were taken after 2 weeks of last vaccination. The eggs from the three groups were collected daily after 2 weeks of the last immunization and stored at $4^{\circ} \mathrm{C}$. The eggs yolk were separated, pooled and kept at $-20^{\circ} \mathrm{C}$ according to Ikemori et al. (1997). One hen group was kept without immunization as negative control.

\section{IgY extraction and Purification}

The method for IgY purification was adapted according to Polson et al. (1980). Briefly, the egg yolk was diluted 1:2 with sterile PBS (pH 7.4). For elimination of lipids and lipoprotein, 3.5\% (wt/vol) polyethylene glycol (PEG) 6000 (Roth, Karlsruhe, Germany) was added. After gentle shaking followed by centrifugation $\left(10,000 \times g\right.$ for $20 \mathrm{~min}$ at $\left.4^{\circ} \mathrm{C}\right)$, the supernatant was decanted and solid PEG 6000 was added to a final concentration of $12 \%$ (wt/vol). This mixture was then centrifuged as above. The precipitate was dissolved in $10 \mathrm{~mL}$ of PBS, PEG was added to $12 \%$ (wt/ vol), and the solution was centrifuged. Finally, the precipitate was dissolved in $1.2 \mathrm{~mL}$ of PBS, transferred into a microdialysis device and dialyzed against $\mathrm{PBS}$ at $4^{\circ} \mathrm{C}$.
The protein content $(\mathrm{mg} / \mathrm{mL})$ was measured photometrically at $280 \mathrm{~nm}$ and was calculated according to the Lambert-Beer law with an extinction coefficient of 1.33 for IgY. And also according to Hoffmann and Richterich (1970).

\section{Screening of chicken anti-FMDV sera and IgY:}

Detection and evaluation of antibody titer against FMDV in hen sera and yolk samples were carried out by serum neutralization test (SNT) and Enzyme Linked Immune Sorbent Assay (ELISA) according to Mettias et al. (1994) and Ikemori et al. (1997) respectively.

\section{Conjugation of FMD-IgY with horse radish peroxidase:}

It was done according to Hudson and Hay (1989) who stated that, dissolve horse radish peroxidase $4 \mathrm{mg} / \mathrm{ml}$ in distilled water, $200 \mu \mathrm{l}$ of sodium periodate solution freshly prepared and stir gently for $20 \mathrm{~min}$. at room temperature, dialyse overnight at $4^{\circ} \mathrm{C}$ against sodium acetate buffer, add $20 \mu$ of sodium carbonate buffer to $\mathrm{pH} 9.5$, and immediately add $1 \mathrm{ml}$ $(8 \mathrm{mg})$ of $\operatorname{IgY}$ protein to be conjugated. Leave at room temperature for 2 hours. After that add $100 \mu \mathrm{l}$ of freshly prepared sodium borohydride solution $(4 \mathrm{mg} / \mathrm{ml})$ in distilled water and leave for 2 hours at 4 ${ }^{\circ} \mathrm{C}$, then dialysis against borate buffer.

\section{Optimization of anti- IgY conjugate}

The optimum titre of anti- IgY -HRP conjugate was determined by preparing several dilutions (1:5 1:1000) from it with PBS $\mathrm{pH}$ 7.4. Each dilution of conjugate was tested with the control positive and control negative antigen according to OIE (2009) and Hiam et al., (2013).

\section{Direct Sandwich ELISA test for FMD antigen serotypes detection.}

It was done according to McCullough et al., (1985), ELISA plate were coated overnight at $4{ }^{\circ} \mathrm{C}$ with $100 \mu \mathrm{L}$ of appropriated dilution $(10 \mu \mathrm{g} / \mathrm{ml})$ protein concentration of rabbit antiserum homologous to antigen being used in carbonate buffer, the liquid phase of viral antigen samples prepared according to Roeder and Le Blanc Smith (1987) were added in $100 \mu$ l, and the modification applied in this method by addition of secondary antibody (chicken IgY conjugated with peroxidase) for each serotypes of FMD viral antigens.Washing the plated three times with (PBS+ tween 20). Then added $100 \mu \mathrm{l}$ OPD substrate and incubation at room temperature in dark place for 10 to15 minutes till change of color from colorless to degree of yellow after that stopping reaction by $50 \mu 1$ of stopping buffer. ELISA plate was reading by ELISA reader at $450 \mathrm{~nm}$. 


\section{Virus neutralization test}

It was done according to OIE (2009), and it performed for the quantitative FMD antibodies in sera of chicken and egg yolk IgY before conjugation.End point titer was expressed as the reciprocal $\log _{10}$ dilution giving $50 \%$ of absorbance estimated according to method of spearman-Karber.

\section{Real time polymerase chain reaction (RT-PCR):}

It was done according EL-Shehawy (2012)

A-RNA extraction: RNA extraction was carried out using the QIAamp®Viral RNAkit (Qiagen, Germany) according to the manufacturer's protocol to all samples in a final volume of $50 \mathrm{ml}$ according to themanufacturer's instruction and stored at $-80^{\circ} \mathrm{C}$ until used.

B-Primers: Primer pair $(\mathrm{PoR} / \mathrm{PoF})$ for real time RTPCR was synthesized by BioBasic, Canada. PoF (5'CCTATG AGAACAAGC GCATC - $3^{\prime}$ ) and PoR (5'CAA CTT CTCCTG TAT GGT CC $-3^{\prime}$ ) were derived from FMDV 3D polymerase for detection of FMDV and have no cross reaction with swine vesicular disease (Universal primer for FMDV).
C-Real-time RT-PCR (rRT-PCR): rRT-PCR was performed using QuantiTect ${ }^{\circledR}$ SYBR ${ }^{\circ}$ Green RTPCR Kit (Qiagen, Germany) as manufacturer's instructions. The cycling parameters were $50{ }^{\circ} \mathrm{C}$ for 30 min and $95{ }^{\circ} \mathrm{C}$ for $15 \mathrm{~min}$; then 30 cycles consisting of $94{ }^{\circ} \mathrm{C}$ for $15 \mathrm{~s}, 55^{\circ} \mathrm{C}$ for $30 \mathrm{~s}$ and $72{ }^{\circ} \mathrm{C}$ for $30 \mathrm{~s}$. Negative control specimen was involved. Each sample was tested in duplicate. PCR amplification was carried out in the Thermo cycler Rotor-GeneQ (Qiagen, Germany)

\section{Samples:}

One hundred tongue epithelium samples; 50 OP fluid fluids and 20 nasal swabs were obtained from naturally infected cattle at Fayoum Governorate in addition to 100 tissue culture infected fluids were subjected to detect FMD viruses using Indirect solid phase Sandwich ELISA; Direct solid phase Sandwich ELISA using IgY conjugated with peroxidase specific for serotypes, and RT-PCR. 


\section{RESULTS}

Table 1: FMDV type O, A and SAT2 antibody titers in chicken sera and egg yolk

\begin{tabular}{|c|c|c|c|c|c|c|c|c|c|c|c|c|}
\hline \multirow{5}{*}{ WPI* } & \multicolumn{12}{|c|}{ Mean FMDV serotypes antibody titers in chicken groups } \\
\hline & \multicolumn{4}{|c|}{ Group (1) } & \multicolumn{4}{|c|}{ Group (2) } & \multicolumn{4}{|c|}{ Group (3) } \\
\hline & \multicolumn{4}{|c|}{ Serotype $(\mathrm{O})$} & \multicolumn{4}{|c|}{ Serotype (A) } & \multicolumn{4}{|c|}{ Serotype (SAT2) } \\
\hline & \multicolumn{2}{|c|}{ NT } & \multicolumn{2}{|c|}{ ELISA } & \multicolumn{2}{|c|}{ NT } & \multicolumn{2}{|c|}{ ELISA } & \multicolumn{2}{|c|}{ NT } & \multicolumn{2}{|c|}{ ELISA } \\
\hline & S & $\mathrm{Y}$ & $\mathrm{S}$ & $\mathrm{Y}$ & $\mathrm{S}$ & $\mathrm{Y}$ & $\mathrm{S}$ & $\mathrm{Y}$ & $\mathrm{S}$ & $\mathrm{Y}$ & S & $\mathrm{Y}$ \\
\hline Pre- immunization & 0 & 0 & 0.01 & 0.01 & 0 & 0 & 0.02 & 0.01 & 0 & 0 & 0.02 & 0.02 \\
\hline Day 0 & 0 & 0 & 0.02 & 0.01 & 0 & 0 & 0.02 & 0.02 & 0 & 0 & 0.02 & 0.01 \\
\hline \multicolumn{13}{|c|}{$1^{\text {st }}$ Immunization with Freund's complete adjuvant } \\
\hline $\begin{array}{l}1^{\text {st }} \text { week post } 1^{\text {st }} \\
\text { Immunization }\end{array}$ & 0.91 & 0.90 & 1.29 & 1.27 & 0.92 & 0.91 & 1.3 & 1.28 & 0.92 & 0.91 & 1.29 & 1.27 \\
\hline \multicolumn{13}{|c|}{$2^{\text {nd }}$ week post $1^{\text {st }}$ Immunization (2nd Immunization with Freund's incomplete adjuvant) } \\
\hline $\begin{array}{l}3^{\text {rd }} \text { week post } 1^{\text {st }} \\
\text { Immunization }\end{array}$ & 1.35 & 1.34 & 1.66 & 1.35 & 1.34 & 1.67 & 1.65 & 1.35 & 1.36 & 1.34 & 1.68 & 1.67 \\
\hline $\begin{array}{l}4^{\text {th }} \text { week post } 1^{\text {st }} \\
\text { Immunization }\end{array}$ & 1.52 & 1.51 & 1.8 & 1.8 & 1.55 & 1.53 & 1.82 & 1.81 & 1.54 & 1.53 & 1.81 & 1.80 \\
\hline \multicolumn{13}{|c|}{$4^{\text {th }}$ week post $1^{\text {st }}$ Immunization ( Booster dose with Freund's incomplete adjuvant) } \\
\hline $\begin{array}{l}5^{\text {th }} \text { week post } 1^{\text {st }} \\
\text { Immunization }\end{array}$ & 2.2 & 2.15 & 2.6 & 2.55 & 2.25 & 2.23 & 2.6 & 2.58 & 2.25 & 2.24 & 2.62 & 2.60 \\
\hline $\begin{array}{l}6^{\text {th }} \text { week post } 1^{\text {st }} \\
\text { Immunization }\end{array}$ & 2.50 & 2.58 & 2.82 & 2.8 & 2.61 & 2.6 & 2.83 & 2.81 & 2.6 & 2.59 & 2.81 & 2.80 \\
\hline
\end{tabular}

Group (1) vaccinated with FMD inactivated Monovalent $\mathrm{O}$

Group (2) vaccinated with FMD inactivated Monovalent A

Group (3) vaccinated with FMD inactivated Monovalent SAT-2

*WPI: Week post immunization

Permissible result for FMDV SNT is $1.5 \log { }_{10} \&$ for ELISA OD is $1.8-1.85$

Mean Permissible titer of IgY NT titer is $2.6 \log _{10}$ and for ELISA OD is $2.8-2.83$ 
Table 2: Sensitivity test of prepared FMD serotypes IgY conjugated with horse radish peroxidase against positive control of FMD serotypes antigens

\begin{tabular}{|c|c|c|}
\hline $\begin{array}{l}\text { FMD serotypes } \\
\text { antigens }\end{array}$ & $\begin{array}{c}\text { Dilution factor of IgY } \\
\text { against serotypes }\end{array}$ & ELISA results \\
\hline \multirow{6}{*}{ FMD serotype O } & $1: 5$ & Positive \\
\hline & $1: 25$ & Positive \\
\hline & $1: 125$ & Positive \\
\hline & $1: 250$ & Positive \\
\hline & $1: 500$ & Positive \\
\hline & $1: 1000$ & Negative \\
\hline \multirow{6}{*}{ FMD serotype A } & $1: 5$ & Positive \\
\hline & $1: 25$ & Positive \\
\hline & $1: 125$ & Positive \\
\hline & $1: 250$ & Positive \\
\hline & $1: 500$ & Positive \\
\hline & $1: 1000$ & Negative \\
\hline \multirow{6}{*}{ FMD serotype SAT-2 } & $1: 5$ & Positive \\
\hline & $1: 25$ & Positive \\
\hline & $1: 125$ & Positive \\
\hline & $1: 250$ & Positive \\
\hline & $1: 500$ & Positive \\
\hline & $1: 1000$ & Negative \\
\hline Control negative & $\begin{array}{c}1: 5 \\
\text { for each anti-FMD } \\
\text { serotypes IgY }\end{array}$ & Negative \\
\hline
\end{tabular}


Table 3: Evaluation of the prepared FMDV-IgY conjugated with horse radish peroxidase

\begin{tabular}{|c|c|c|c|c|}
\hline \multirow[b]{2}{*}{ Tested samples } & \multirow[b]{2}{*}{$\begin{array}{c}\text { Virus } \\
\text { serotype }\end{array}$} & \multicolumn{3}{|c|}{ Percentage of positive samples using the applied tests } \\
\hline & & $\begin{array}{c}\text { Traditional } \\
\text { ELISA typing }\end{array}$ & RT-PCR & $\begin{array}{c}\text { ELISA using the } \\
\text { prepared IgY ELISA }\end{array}$ \\
\hline \multirow{4}{*}{$\begin{array}{l}100 \text { Tongue } \\
\text { epithelium }\end{array}$} & $\mathrm{O}$ & 65 & 70 & 70 \\
\hline & $\mathrm{A}$ & 10 & 15 & 13 \\
\hline & SAT2 & 5 & 7 & 7 \\
\hline & $-\mathrm{ve}$ & 20 & 8 & 10 \\
\hline \multirow{4}{*}{50 OP fluids } & $\mathrm{O}$ & 20 & 22 & 22 \\
\hline & $\mathrm{A}$ & 13 & 13 & 13 \\
\hline & SAT2 & 13 & 14 & 14 \\
\hline & -ve & 4 & 1 & 1 \\
\hline \multirow{4}{*}{$\begin{array}{l}20 \text { Nasal } \\
\text { swabs }\end{array}$} & $\mathrm{O}$ & 6 & 7 & 7 \\
\hline & $\mathrm{A}$ & 4 & 5 & 5 \\
\hline & SAT2 & 3 & 3 & 3 \\
\hline & -ve & 7 & 5 & 5 \\
\hline
\end{tabular}

\section{DISCUSSION}

The definitive FMD diagnosis should be based on complex laboratory testing including indirect Sandwich ELISA and RT-PCR methods combined with virus isolation on cell culture ( BHK, Pig or lamb kidney) as a gold standard method recommended by OIE. Depending on the great importance of FMD, accurate and rapid identification of the causative agent is an essential step in controlling the disease. This purpose needs the availability of specific diagnostic antiserum for each serotypes and kits which may be not available on request. So, the present work was designed to prepare anti-FMD (local types O, A and SAT2) IgY conjugated with horse radish peroxidase to saving time and cost where such IgY will be prepared in chicken egg yolk.

The yolk of eggs laid by immunized chickens has been recognized as an excellent source of polyclonal antibodies. Using chicken as the immunization host for producing egg yolk antibodies (IgY) instead of IgG from mammalian species brings a number of advantages: (1) the animal suffering is reduced (no bleeding), as antibodies are obtained directly from the egg and only egg collection is required upon immunization, (2) antibody isolation is fast and simple; (3) very low quantities of antigen are required to obtain high and long-lasting immunoglobulin titers in the egg yolk from immunized hens, and (4) a single egg contains as much antibodies as an average bleed from a rabbit
Davalos-Pantoja et al., (2000); Schade and Hlinak (1996); Tini et al., (2002).

Using chicken as a host for antigen immunization and generation of polyclonal antibodies ( $\operatorname{IgY}$ ) has demonstrated several valuable advantages over existing mammalian systems as discussed by Sock et al., (2012). The obtained results through the present work showed that chicken immunization with the monovalent FMD serotypes ( $\mathrm{O}$; A, and SAT-2) induced detectable antibodies against FMD serotype O, A and SAT2 by the first week post immunization as determined by VNT in chicken sera and egg yolk as $0.91 \& 0.9 ; 0.92 \& 0.91$, and $0.92 \& 0.91$ for each serotypes respectively. And antibody titer against FMD serotypes measured by ELISA were $1.29 \& 1.27 ; 1.3 \& 1.28$, and $1.29 \& 1.27$ respectively .

These antibody titers against FMD serotypes were gradually increased by the 2 nd immunization (4th week post the first immunization) as shown in table (1) recording their peaks for serotype $\mathrm{O}(2.5 \& 2.48$ by VNT and $2.82 \& 2.8$ by ELISA in chicken sera and egg yolk respectively; for serotype A $(2.61 \& 2.6$ by VNT and $2.83 \& 2.81$ by ELISA, and for serotype SAT-2 (2.6\& 2.59 by VNT and $2.81 \& 2.8$ by ELISA) respectively. These findings agree with what reported by OIE (2013) concluded that such antibody titers are protective and Gamal et al., (2015) obtaining similar findings. Antibodies are useful for specifically recognizing antigens and the detection of antigen-antibody complex could be easy when precipitation occurs. Labeling of antibodies makes antigen identification easier. 
As shown in (table 2) the sensitivity of prepared IgY specific for each FMD serotypes was 1/500 with specific control positive of FMD viral antigen serotypes Specific, rapid and sensitive serological tests like enzyme linked immune sorbent assay (ELISA) are required for accurate diagnosis of infectious agents to reach to well applicable control measures. It was concluded that ELISA was successful in the specific detection of FMDV from infected tissue culture and epithelial tissues. The ELISA compared favorably with the complement fixation test, being more sensitive and unaffected by anti-complementary factors Crowther and Abu ElZein, (1979). The use of an indirect technique of ELISA was efficient in detecting FMDV in cell culture fluids, mouse carcasses and cattle tongue epithelium.

The technique was also recommended for detecting serum antibody titers Rai and Lahiri, (1981). Hamblin et al., (1986) utilized ELISA for the detection of antibodies against FMD by titration of serum antibodies from more than 300 British uninfected and non vaccinated animals against the 7 immunologically distinct (FMDV) types. It was found that such Igy had a total protein value of 7.54, 7.2 and $7.4 \mathrm{gm} / \mathrm{dl}$ for O, A and SAT2 respectively; in this respect similar findings were obtained by Manal and Mervat (2008) who found that the immune globulin of the prepared FMD antiserum type-A was found to be $12.5 \mathrm{gm} / \mathrm{dl}$. The obtained IgY FMD antibody titters (Table-1) were 2.58 and $2.80 ; 2.60$ and $2.81 ; 2.81$ and 2.80 by SNT and ELISA for type O; A and SAT2 respectively. These high FMD antibody titers came in agreement with those of Barnett et al., (1996) and Abd El-Karim (2007) who concluded that Mantonid oil ISA-206 has the ability to improve the immune response of vaccinated animals with FMD vaccine resulted in higher levels of immunity.

Such IgY was successfully conjugated with horse radish peroxidase and detection of the three types of FMD virus was carried out in 100 tongue epithelium samples; 50 OP fluid samples; 20 nasal swabs obtained from naturally infected cattle in addition to 100 tissue culture infected fluids using traditional ELISA; RT-PCR and ELISA using the prepared conjugated IgY (Table-2). The results of three techniques came in a parallel manner confirming each other. So the prepared FMD IgY conjugated with horse radish peroxidase could be considered of diagnostic benefit in detection and typing of FMD virus providing local preparation available on request. And from economic value, Direct Sandwich ELISA where used one type only of secondary antibody (IgY conjugation against each serotype) while Indirect Sandwich ELISA need for anti-guinea pig as secondary antibody and also antianti-guinea pigs labeled by peroxidase.

\section{CONCLUSION}

It can be concluded that, the prepared FMD IgY conjugated with horse radish peroxidase could be considered of diagnostic benefit in detection and typing of FMD virus providing local preparation available on request.

\section{REFERENCES}

ABD EL-KARIM, A.S. 2007. Comparative studies on foot and mouth disease vaccine containing different adjuvants in sheep. M.Vet.Sci.Thesis (Infectious Diseases), Fac.Vet.Med.Cairo Univ.

ABD EL-RAHMAN, A.O.; FARAG, M.A.; SAMIRA ELKILANY; ALI, S.M. AND MANAL, ABO ELYAZEID AND ZEIDAN, S.M. 2006. Isolation and identification of foot and mouth disease virus during an outbreak of 2006 in Egypt. J. Kafr El-Sheikh Vet. Med. 4 (1): 451-464

AIDAROS, H. A. 2002. Regional status and approaches to control and eradication of FMD in the Middle East and North Africa. Rev. Sci. tech. Off. Int. Epiz., 21 (3): 451458.

BARNETT, P., PULLEN, L., WILLIAMS, L., DOEL, T.R., 1996. Assessment of Montanide ISA 25 and ISA 206, two commercially available oil adjuvant. Vaccine 14 (13), 1187-1198.

CROWTHER, J.R. AND ABU EL-ZEIN, E.M.E. 1979. Application of enzyme linked immunosorbent assay to the detection and identification of Foot and Mouth Disease viruses. J. Hyg., 83 (3): 513-519.

DAVALOS-PANTOJA, L., ORTEGA-VINUESA, J. L., BASTOS- GONZALEZ, D., HIDALGO-ALVAREZ, R. 2000. A comparative study between the adsorption of IgY and IgG on latex particles. J. Biomater. Sci. Polym Ed. 11: 657-673.

DEPA PM, DIMRI U, SHARMA MC, TIWARI R. 2012. Update on epidemiology and control of Foot and Mouth Disease - A menace to international trade and global animal enterprise, Vet World, 5(11): , 694-704.

EL-SHEHAWY L, AZAB AMH, MOSSAD W, EL-SAYED E, ISMAIL A, DEGHADY W, 2012. Real time RT-PCR assay for detection of different serotypes of FMDV in Egypt, Vet World, 5(12): 732-737, doi: 10.5455/vetworld.2012.732-737

FARAG, M.A.; AGGOUR, A.M. AND DAOUD, A.M. 2005. ELISA as a rapid method for detecting the correlation between the field isolates of foot and mouth disease and the current used vaccine strain in Egypt. J.Vet.Med.Giza, 53 (4): 949-955.

FARAG M A, EMAN M EL-GARF AND HIAM M FAKHRY, 2011. Emergency Vaccination Of Cattle Using Foot And Mouth Disease Vaccine. Zag. Vet. J. (ISSN. 1110-1458) Vol. 39 No. 2 pp.188-198. 
GAMAL, W.M.; MOUNIR, M.I.; EL-HELOW, H. A. AND KHODEIR, M.H. 2015. Using of FMD antibody prepared in chicken egg yolk for emergency immunization of cattle. J. Egypt vet. Med. Assoc. 75, no.4 605-624.

HAMBLIN, C., BARNETT, I.T.R. AND CROWTHER, J.R.1986. A new enzyme linked immunosorbent assay (ELISA) for the detection of antibodies against FMD virus. II. Application. J. Immunol. Meth., 93: 123- 129.

HIAM, M. FAKHRY, KHOUDEIR M. AND ., HANAA A. MOSTAFA, 2013.

Comparative studies on foot and mouth disease SAT 2 hyper immune sera prepared in different hosts conjugated with flourescein isothiocyanate and horse radish peroxidase . 6th Sci. Congr. of Egypt. Soc. For Anim. Manag. 27-31 August.,: 14 -23.

HOFFMANN, J. P. AND RICHTERICH, R. 1970. The elimination of turbidity in the determination of plasma proteins with Biuret reagent. Z. Klin, chem.. J. Klin. Biochem., 8:595-598.

HUDSON, L., AND HAY, F. C. 1989. Practical Immunology 3rd Ed. Blackwell Scientific Publications Oxford London. ISBN. 0-632-01491-1

IKEMORI, Y.; OHTA, M.; UNEDA, K.; I CATLO, FC. JR.; KUROKI, M.; YOKOYAND, H. AND KODANA, Y. 1997. Passive protection of neonatal calves against bovine coronavirus - induced diarrhea by administration of egg yolk or colostrum antibody powder. Vet Microbiol., 58 (2-4): 105-111.

KARLSSON, M., KOLLBERG, H., LARSSON, A., 2004. Chicken IgY: utilizing the evolutionary advantage. World's Poult. Sci. J. 60, 341.

LESLIE GA and CLEM LW. 1969. Phylogen of immunoglobulin structure and function. Immunoglobulins of the chicken. J Exp Med. 130:1337-52.

MANAL ABOEL-YAZED MUSTAFA AND MERVAT M.ALI. 2008. Preparation of anti-FMD virus typeA immuno globuline conjugated with horse radish peroxidase and fluorescein isothiocyanate for serological use. J. Egypt. Vet. Med. Assoc. 68(3) 2008, Arab vet.. Medical congress. (15-17) December 2008, pp.(129-139).

MCCUlloUGH, K. K.; CROWTHER, J. R., AND BUTCHER, R. N. 1985. A liquid -phase ELISA and its use in the identification of epitopes of Foot and mouth disease virus antigen. J. Virol. Methods. 11: 329-338.

METTIAS, K.N.; EL - RASHIDY.; A. A.; EL-GHARHI, M.; HUSSIEN, N. N.; HASSEN, E. R.; SALEH, S. M. AND EL - DANAF, N. A. 1994. Studies on the protection of bovine neonats against diarrhea by vaccination with trivalent vaccine (Rota, Corona, K99) - Estimation of K99 antibodies invaccinated dams and their neonates. Zag. Vet. J., 22 (3): 137 142.

NEETA LONGJAM, DEB R, SARMAH AK, TAYO T, AWACHAT VB, SAXENA VK. 2011. A Brief Review on Diagnosis of Foot-and-Mouth Disease of Livestock: Conventional toMolecular Tools. Veterinary Medicine International Volume 2011,
Article ID 905768, 17 pages, doi:10.4061/2011/905768.

OIE. 2009. OIE Terrestrial Manual, Foot and Mouth Disease chapter 2.1.05

OIE. 2013. OIE/FAO Foot-and-Mouth Disease Reference Laboratory Network,Annual Report 2013.

PARIDA SATYA. 2009. Vaccination against foot $^{-}$and- mouth disease virus strategies and effectiveness Expert Rev. Vaccines 8(3), 347-365.

POLSON , A. , VON WECHMAR , M. B., AND VAN REGENMORTEL, M. H. 1980 . Isolation of viral IgY antibodies from yolks of immunized hens. Immunol. Commun. $9: 475-493$.

RAI, A. AND LAHIRI, D.K. 1981. A micro-enzyme labeled immunosorbent assay (micro- ELISA) for the detection of Foot and Mouth Disease virus antigen and antibody. Acta. Virol., 25 (1): 49-52.

ROEDER, P. L. AND LE BLANC SMITH, P. M. 1987. Detection and typing of foot-and-mouth disease virus enzyme linked Immunosorbent assay: A sensitive, rapide and reliable technique for primary diagnosis. Res. Vet. Sci. 43: 225-232.

SAFY E. M .2011. Evaluation of emergency vaccination against Foot and Mouth disease using bivalent type $\mathrm{A} \& \mathrm{O} 1 . \mathrm{PhD}$, faculty of veterinary medicine, Benha University

SCHADE, R., HLINAK, A. 1996. Egg Yolk Antibodies. State of the Art and Future Prospects. ALTEX. 13:59.

SHAWKY M., ABD EL-ATY M., HIAM. M. FAKRY, HIND M. DAOUD, EHAB EL-SAYED I., WAEL MOSSAD G., SONIA A. RIZK, ABU-ELNAGA H., MOHAMED A. A., ABD EL-KREEM A. AND FAROUK E. M. 2013. Isolation and Molecular Characterization of Foot and Mouth Disease SAT2 Virus during Outbreak 2012 in Egypt. J Vet Adv 2013, 3(2): 60-68. DOI: 10.5455/jva.20130219104353.

SOCK HWEE TAN, ABIDALI MOHAMEDALI, AMIT KAPUR, LAURA LUKJANENKO, MARK S. BAKER .2012. A novel, cost-effective and efficient chicken egg IgY purification procedure. Journal of Immunological Methods 380 (2012) 73-76

TINI, M., JEWELL, U. R., CAMENISCH, G., CHILOV, D., GASSMANN, M. 2002. Generation and application of chicken egg-yolk antibodies. Comp. Biochem. Phys.131: 569-574.

XUAN H., LI Y., FANG, H. AND ZHENG, C. 2011. Establishment of persistent infection with foot and mouth disease virus in BHK21 cells. Virol. J., 8: 169. 